\title{
A proportional study of cancer registrations of dockyard workers
}

\author{
K. P. S. LUMLEY \\ Medical Research Unit, H.M. Naval Base, Devonport, Plymouth, Devon
}

\begin{abstract}
Lumley, K. P. S. (1976). British Journal of Industrial Medicine, 33, 108-114. A proportional study of cancer registrations of dockyard workers. Evidence of an occupational effect due to asbestos exposure was sought by comparing cancer registrations for dockyard workers with those for Plymouth men in the same age groups for 1960-69. The results show a significant excess of pleural tumours in the dockyard group but no significant excesses at other sites. Registrations for pleural mesothelioma were recorded for men with many dockyard occupations and the observed mean interval between first exposure to asbestos and registration for a pleural tumour (37.6 years) indicates that cases of pleural mesothelioma may be expected to occur among these workers for many years, even though crocidolite is no longer used in naval ships. A trend of increasing annual excess of stomach and gastrointestinal registrations was observed in the dockyard group. No cases of peritoneal mesothelioma were recorded but it is likely that some did occur which were diagnosed as cancers arising from other sites. This may account for some of the excess of gastrointestinal registrations.
\end{abstract}

The Royal Naval Base at Devonport, Plymouth, employs about 14000 men, many of whom are directly employed in refitting warships. Before strict precautions were introduced to control the use of asbestos in naval dockyards, many of these men had had varying amounts of exposure to crocidolite (blue), amosite, and chrysotile asbestos (Harries, 1968). A dust sampling survey (Harries, 1971a) also showed that there had been high concentrations of airborne asbestos dust in the ships during refits, and a radiological survey showed that the prevalence of abnormalities associated with asbestos was about $4 \%$ in this population (Sheers and Templeton, 1968).

The risk of developing lung cancer is increased in those exposed to asbestos. Epidemiological studies by Doll (1955) and Knox et al. (1968) suggested that the risk of developing lung cancer was high when the risk of developing asbestosis was high, but fell to that in the general population when asbestos exposure was low and unlikely to cause asbestosis. However, neither of these studies considers the effect of smoking, and Selikoff, Hammond, and Churg (1968) and Berry, Newhouse, and Turok (1972) showed that smoking augments considerably the asbestos related risk of developing lung cancer. The risk of developing mesothelioma of the pleura and peritoneum is particularly associated with exposure to crocidolite but this risk is less certainly related to dose (Wagner, et al., 1971).

It is suspected that asbestos exposure may increase the risk of developing malignant tumours at other sites. Selikoff, Churg, and Hammond (1964) reported a threefold excess in mortality from gastrointestinal cancer in New York insulation workers. Elmes and Simpson (1971) also found an excess number of deaths from gastrointestinal cancers in Belfast insulation workers, and Newhouse (1973) reported a significant excess of deaths not only from thoracic cancers but also from 'other cancers' in men followed-up for 25 years after two or more years' exposure to asbestos.

It has also been suggested that asbestos exposure may be implicated in the aetiology of cancers of the orophanyx (Selikoff, Hammond, and Churg, 1970), the larynx (Stell and McGill, 1973), haematopoietic tissue (Gerber, 1970), and the ovary (Keal, 1960). 
In this study evidence of an occupational effect due to asbestos exposure on the occurrence of malignant tumours in dockyard workers as a whole has been sought by comparing cancer registrations for male dockyard workers with those for all males living in the Plymouth area.

\section{Methods}

\section{Population}

The cancer registrations recorded at the Plymouth office of the South Western Regional Cancer Registry between 1960 and 1969 were examined, and all registrations for males aged 15 years and over whose addresses were in the Plymouth area at the time of registration were included in the study. The Plymouth area was defined as the City of Plymouth and the adjoining rural districts of Plympton and St Germans.

\section{Data recorded}

Full name, address, date of birth, year of registration, diagnosis, and occupation were recorded for each individual. The occupation as stated on the death certificate was recorded for those who had died; this was usually available at the Cancer Registry, but if not, the occupation was obtained either from a copy of the death certificate or from the Returns of Deaths to Sanitary Authorities for Plymouth and Plympton. Dockyard workers were identifiable because of the addition of the letters HMD after the occupation recorded on the death certificate. Dockyard workers among those who had not died were identified by tracing them in the Naval Base employment records.

All the information was coded numerically for analysis, using the Eighth Revision of the International Statistical Classification of Diseases (World Health Organization, 1967) to classify diagnosis.

Analysis

The registrations were divided into those for dockyard workers, both currently employed and retired, and all other Plymouth males. The registrations for these two groups were tabulated by age and diagnosis in five-year age groups for each year of the study and for 1960-69 combined.

Because the age structure of the dockyard population was not known, expected numbers for that group were calculated using the proportional method proposed by the Registrar General (1968a). For example, in Table 1 at age 55-59 years there were 189 registrations for thoracic cancers out of 602 registrations for all types of cancer in Plymouth males as a whole, and there were 193 registrations for all types of cancer in dockyard workers, so that the expected number of registrations for thoracic cancers in dockyard workers would be $193 \times \frac{189}{602}=60.6$.

Expected numbers calculated by this method for each five-year age group were summed to obtain an expected number for all ages over 15 years, and a Proportional Registration Ratio (PRR), which is the ratio of the observed to the expected number $\times 100$, was calculated. Thus, from Table 1, the PRR for thoracic cancers in dockyard workers $=\frac{388}{347 \cdot 4} \times 100=111 \cdot 7$. The deviations below expected were not assessed for significance because, using this method, excess registrations for one site must be matched by deficiencies elsewhere.

\section{Results}

Between 1960 and 1969, 4998 cancer registrations were recorded for Plymouth males aged 15 years and over, of which 1377 were for dockyard workers.

\section{Local comparison}

The observed and expected number of cancer registrations for dockyard workers based on the cancer

TABLE 1

Cancer Registrations for Dockyard Workers and All Plymouth Males 1960-69

\begin{tabular}{|c|c|c|c|c|c|}
\hline \multirow{2}{*}{ Age } & \multicolumn{2}{|c|}{ Thoracic cancers (ISC 162-3) } & \multicolumn{2}{|c|}{ All cancers (ISC 140-209) } & \multirow{2}{*}{$\begin{array}{l}\text { Expected no. } \\
\text { of thoracic cancers } \\
\text { in dockyard workers }\end{array}$} \\
\hline & Dockyard & Plymouth & Dockyard & Plymouth & \\
\hline $\begin{array}{l}15- \\
20- \\
25- \\
30- \\
35- \\
40- \\
45- \\
50- \\
55- \\
60- \\
65- \\
70- \\
75+\end{array}$ & $\begin{array}{r}0 \\
0 \\
0 \\
1 \\
1 \\
3 \\
20 \\
23 \\
67 \\
102 \\
82 \\
50 \\
39\end{array}$ & $\begin{array}{r}0 \\
1 \\
1 \\
1 \\
5 \\
15 \\
62 \\
105 \\
189 \\
270 \\
242 \\
178 \\
147\end{array}$ & $\begin{array}{r}2 \\
5 \\
4 \\
4 \\
16 \\
23 \\
49 \\
74 \\
193 \\
258 \\
241 \\
216 \\
292\end{array}$ & $\begin{array}{r}16 \\
17 \\
27 \\
39 \\
72 \\
109 \\
206 \\
333 \\
602 \\
766 \\
858 \\
813 \\
1140\end{array}$ & $\begin{array}{r}\overline{0} \\
0 \cdot 3 \\
0 \cdot 1 \\
0 \cdot 1 \\
1 \cdot 1 \\
3 \cdot 2 \\
14 \cdot 7 \\
23 \cdot 3 \\
60 \cdot 6 \\
90 \cdot 9 \\
68 \cdot 0 \\
47 \cdot 3 \\
37 \cdot 7\end{array}$ \\
\hline All ages over 15 yrs & 388 & 1216 & 1377 & 4998 & $347 \cdot 4$ \\
\hline
\end{tabular}

ISC = International Statistical Classification of Diseases (1967) 
registrations for Plymouth males for 1960-69 are shown in Table 2. There was a very small excess of cancers of the buccal cavity and pharynx, and a small excess of cancers of the gastrointestinal tract as a whole, which was associated within the gastrointestinal tract with excesses of stomach and pancreatic cancers, but none was significant. No excesses were found for cancers of the oesophagus, small intestine, colon, and rectum and the figures for these sites have been omitted from Table 2 . No registrations for peritoneal mesothelioma were recorded.

There was a significant excess of cancers of the respiratory tract as a whole, but this was confined to cancers of the thoracic organs, and there was no significant excess of cancers of the upper respiratory tract and the larynx. On further analysis the significance of the excess of thoracic cancers was confined to the pleural tumours, and the excess of lung cancer was not significant, though it was numerically larger than that for the pleural tumours.

A small insignificant excess was found for cancers for which no site was specified, but there was no excess of cancers of haematopoietic tissue, lymphoid tissue, and cancers at 'all other sites'.

\section{Pleural tumours}

The excess of pleural tumours was due to the registration of 22 cases of pleural mesothelioma and one case of pleural endothelioma for the dockyard workers compared with only three cases of pleural mesothelioma in other Plymouth males. Details of the year and age at registration, age at death, occupation, and asbestos exposure where this information was available for the $\mathbf{2 6}$ men are given in Table 3. The mean ages were 60.3 years (range $39-82$ ) at registration and 60.8 years (range 39-85) at death. For those for whom the information was available, the mean number of years between first exposure to asbestos and registration for a pleural tumour was 37.6 years (range 23-69; 19 men) and the mean number of years of asbestos exposure was 28.7 years (range 12-47; $18 \mathrm{men}$ ). The occupations of the men for whom details of asbestos exposure were not known suggested that they had also been exposed to asbestos. The population of the Plymouth area includes about 100000 men aged 15 years and over. Estimates of the mesothelioma rates from Scotland (McEwen et al., 1970) and from Canada (McDonald et al., 1970) give values of between 0.7 and one per million a year. Thus, the expected number in 10 years in Plymouth would be about one case. Even the railway fitter was known to have been exposed to asbestos, but it is of interest that one case of pleural mesothelioma in a bank employee was registered in 1970.

\section{Annual trends}

Evidence of annual trends of excesses was sought by calculating the annual excesses for stomach, gastrointestinal, lung, and pleural tumours in the dockyard workers for each year of the study. The results are shown in the figure. The numbers involved are relatively small, but they suggest a trend of increasing excesses of stomach and gastrointestinal registrations together with a decreasing trend for lung cancer for the dockyard workers during the period studied.

TABLE 2

Observed and Expected Cancer Registrations and Proportional Registration Ratios for Dockyard Workers Compared With Plymouth Males 1960-69

\begin{tabular}{|c|c|c|c|c|c|}
\hline \multirow{2}{*}{ Site } & \multirow{2}{*}{ ISC No. } & \multicolumn{2}{|c|}{ Dockyard } & \multirow{2}{*}{$P R R$} & \multirow{2}{*}{$P$} \\
\hline & & Observed & Expected & & \\
\hline Buccal cavity and pharynx & $140-9$ & 53 & $51 \cdot 3$ & $103 \cdot 3$ & NS \\
\hline $\begin{array}{l}\text { Stomach } \\
\text { Pancreas } \\
\text { Gastrointestinal tract }\end{array}$ & $\begin{array}{l}151 \\
157 \\
150-9\end{array}$ & $\begin{array}{r}179 \\
46 \\
416\end{array}$ & $\begin{array}{r}157 \cdot 1 \\
42 \cdot 2 \\
408 \cdot 5\end{array}$ & $\begin{array}{l}113 \cdot 9 \\
109 \cdot 0 \\
101 \cdot 8\end{array}$ & $\begin{array}{l}\text { NS } \\
\text { NS } \\
\text { NS }\end{array}$ \\
\hline $\begin{array}{l}\text { Upper respiratory tract } \\
\text { Larynx } \\
\text { Lung } \\
\text { Pleura } \\
\text { Thoracic } \\
\text { Respiratory tract }\end{array}$ & $\begin{array}{l}160-1 \\
161 \\
162 \\
163 \cdot 0 \\
167-3 \\
160-3\end{array}$ & $\begin{array}{r}24 \\
20 \\
363 \\
23 \\
388 \\
412\end{array}$ & $\begin{array}{r}22 \cdot 5 \\
18 \cdot 5 \\
338 \cdot 0 \\
8 \cdot 1 \\
347 \cdot 4 \\
369 \cdot 8\end{array}$ & $\begin{array}{l}106 \cdot 7 \\
108 \cdot 1 \\
107 \cdot 4 \\
282 \cdot 7 \\
111 \cdot 7 \\
111 \cdot 4\end{array}$ & $\begin{array}{l}\text { NS } \\
\text { NS } \\
\text { NS } \\
\leqslant 0.0001 \\
<0.02 \\
<0.02\end{array}$ \\
\hline $\begin{array}{l}\text { Lymphoid tissue } \\
\text { Haematopoietic tissue }\end{array}$ & $\begin{array}{l}200-2 \\
200-9\end{array}$ & $\begin{array}{l}24 \\
57\end{array}$ & $\begin{array}{l}28 \cdot 3 \\
61 \cdot 5\end{array}$ & $\begin{array}{l}84 \cdot 8 \\
92 \cdot 7\end{array}$ & - \\
\hline Site unspecified & 199 & 40 & $33 \cdot 2$ & $120 \cdot 5$ & NS \\
\hline All other sites & $170-198$ & 399 & $451 \cdot 9$ & $88 \cdot 3$ & - \\
\hline
\end{tabular}


TABLE 3

Year and Age at Registration, Age at Death, Occupation and Asbestos Exposure (where known) for Plymouth Males with Cancer Registrations for Pleural Tumours (1960-69)

\begin{tabular}{|c|c|c|c|c|c|}
\hline \multicolumn{6}{|c|}{ Dockyard workers } \\
\hline \multicolumn{2}{|c|}{ Registration } & \multirow{2}{*}{$\underset{\text { death }}{\text { Age at }}$} & \multirow{2}{*}{ Occupation } & \multicolumn{2}{|c|}{ Asbestos exposure (years) } \\
\hline Year & Age & & & Since first exposed & Total exposure \\
\hline $\begin{array}{l}1968 \\
1969\end{array}$ & $\begin{array}{l}58 \\
58 \\
69 \\
65 \\
64 \\
64 \\
56 \\
46 \\
65 \\
61 \\
78 \\
53 \\
80 \\
53 \\
60 \\
59 \\
39 \\
64 \\
43 \\
49 \\
61 \\
50 \\
82\end{array}$ & $\begin{array}{l}58 \\
58 \\
70 \\
66 \\
64 \\
65 \\
56 \\
46 \\
66 \\
62 \\
79 \\
56 \\
80 \\
53 \\
61 \\
59 \\
39 \\
64 \\
43 \\
49 \\
61 \\
50 \\
85\end{array}$ & $\begin{array}{l}\text { Boilermaker* } \\
\text { Boilermakers assistant } \\
\text { Skilled labourer } \\
\text { Supervisor of shipwrights } \\
\text { Shipwright } \\
\text { Supervisor of boilermakers } \\
\text { Shipwright } \\
\text { Boilermakers assistant } \\
\text { Instructor } \\
\text { Technical officer } \\
\text { Skilled labourer } \\
\text { Draughtsman } \\
\text { Shipwright } \\
\text { Skilled labourer } \\
\text { Electrical fitter } \\
\text { Supervisor of welders } \\
\text { Welder } \\
\text { Electrical fitter } \\
\text { Shipwright } \\
\text { Caulker riveter } \\
\text { Electrical fitter } \\
\text { Caulker riveter } \\
\text { Labourer }\end{array}$ & $\begin{array}{c}\text { Not known } \\
32 \\
\text { Not known } \\
49 \\
\text { Not known } \\
\text { Not known } \\
34 \\
28 \\
35 \\
31 \\
57 \\
35 \\
59 \\
\text { Not known } \\
28 \\
42 \\
25 \\
\text { Not known } \\
23 \\
31 \\
45 \\
32 \\
69\end{array}$ & $\begin{array}{c}\text { Not known } \\
31 \\
23 \\
\text { Not known } \\
34 \\
\text { Not known } \\
\text { Not known } \\
28 \\
34 \\
30 \\
40 \\
18 \\
\text { Not known } \\
\text { Not known } \\
28 \\
41 \\
24 \\
\text { Not known } \\
23 \\
30 \\
12 \\
31 \\
47\end{array}$ \\
\hline \multicolumn{6}{|c|}{ Other Plymouth males } \\
\hline $\begin{array}{l}1968 \\
1969\end{array}$ & $\begin{array}{l}77 \\
58 \\
56\end{array}$ & $\begin{array}{l}77 \\
59 \\
56\end{array}$ & $\begin{array}{l}\text { Railway fitter } \\
\text { Supervisor power station } \\
\text { Bookseller (ex engine room branch Royal } \\
\text { Navy) }\end{array}$ & $\begin{array}{l}\text { Not known } \\
22 \\
37\end{array}$ & $\begin{array}{l}\text { Not known } \\
21 \\
22\end{array}$ \\
\hline
\end{tabular}

${ }^{*}$ Registered as endothelioma. All other registrations were for mesothelioma.

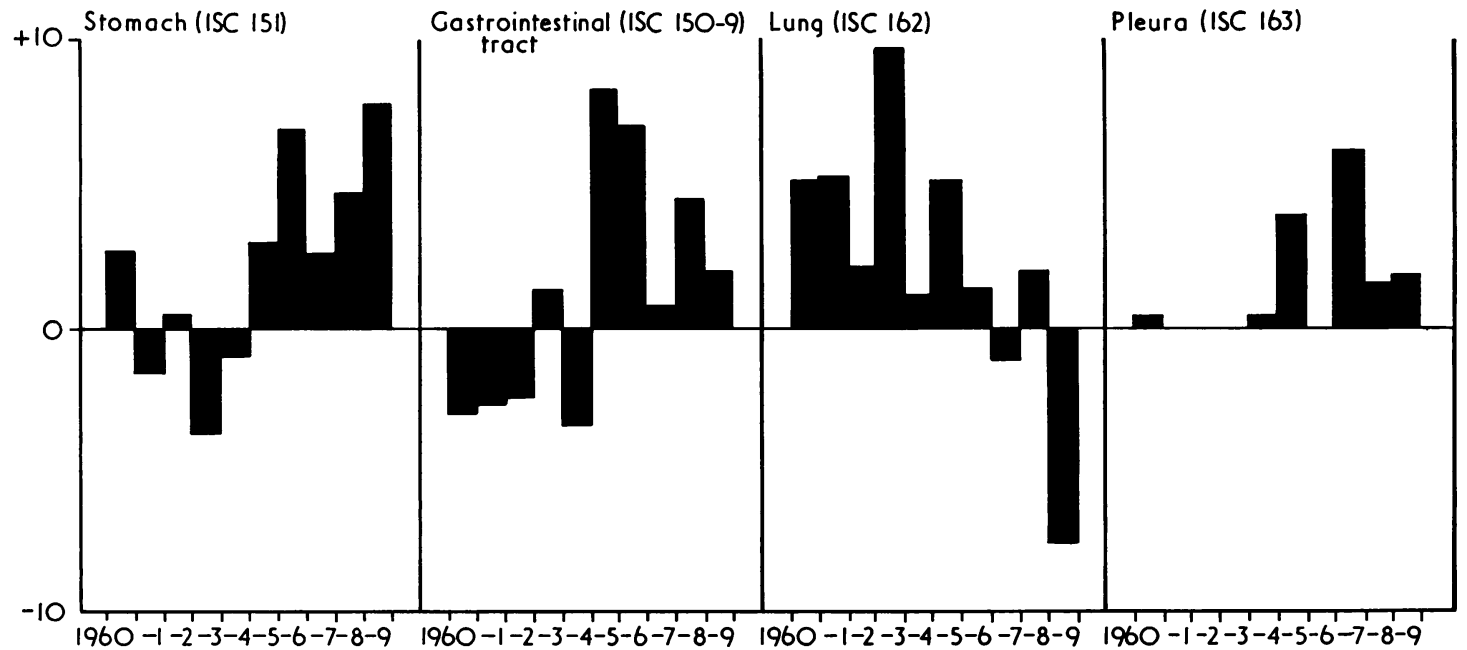

FIGURE Observed minus expected cancer registrations for dockyard workers aged 15 years and over by year and site 1960-69. 
There were few pleural tumours recorded each year which may account for the absence of any definable trend of excess for these tumours.

\section{Death certificate registrations}

To make the registration of cancers as complete as possible the Plymouth office of the South Western Regional Cancer Registry is notified of all deaths of people living in the Plymouth area in which cancer is mentioned on the death certificate as one of the causes of death. These cases are recorded as 'death certificate registrations' if they have not been registered previously. They tend to be recorded for elderly people and there is usually little or no additional clinical or pathological information available in the Registry record to support the diagnosis. It was considered important to analyse these registrations separately to see if there were substantially more of them for the dockyard workers than for other Plymouth males.

Between 1960 and 1969, 273 death certificate registrations were recorded for Plymouth males of which 72 were for dockyard workers. Table 4 shows no evidence of differences between dockyard workers and other Plymouth males. In fact the expected number of such cases among dockyard workers is $75 \cdot 2$, just more than the observed 72 . The proportions of these registrations, expressed as a percentage of the total number of registrations, were also similar for each site. It was interesting to find that stomach cancer was more commonly registered in this way than any of the other types of cancer. It was also found that, as expected, over half of the death certificate registrations were for men aged 75 years and over.

\section{Discussion}

A study of cancer registrations should give more information about the occurrence of cancer than a mortality study because people who develop cancer do not necessarily die of cancer. There is, however, the disadvantage that the registration of cancer may be incomplete. The Registrar General (1968b) reported evidence of variation in the completeness of cancer registration throughout England and Wales, showing in fact that the South Western Regional Cancer Registry was above average for registration.

This study would be biased if the cancer registrations for dockyard workers were more, or less, complete than those for other Plymouth males. There is no reason to believe this to be so, and the overall registration rates per 100000 of the population in Plymouth and in the South Western Region are similar suggesting that any such bias that may exist can only be small.

Expected numbers for dockyard workers could also have been calculated on the basis of cancer registrations for all males aged 15 years and over in either the South Western Region or England and Wales for 1962-68. This would have been misleading. Table 5 shows that for stomach cancer registrations in dockyard workers the PRR is 144 when compared with the South Western Region. However, for other Plymouth males the corresponding PRR is 120 showing that stomach cancer registration is high in the Plymouth area anyway. The PRR for gastrointestinal cancers is also significantly higher in the Plymouth area whereas that for thoracic cancers is significantly lower, and the simple comparison with England and Wales would have shown an apparent, and erroneous, deficiency of thoracic cancers. For these reasons the findings from the local comparison with Plymouth males is thought to provide a better guide to the possible effects of asbestos exposure on the occurrence of cancers in the dockyard workers than a comparison based on either regional or national cancer registrations.

In a proportional mortality study by Harries (1971b) no significant excesses of thoracic and gastrointestinal cancers were found in the dockyard workers. In that study the pleural tumours could not

TABLE 4

Number of Death Certificate Registrations with Percentages of All Registrations at Each Site for 1960-69 COMBINED

\begin{tabular}{|c|c|c|c|c|c|c|c|c|}
\hline $\begin{array}{c}\text { Site } \\
\text { (ISC No.) }\end{array}$ & $\begin{array}{c}\text { Stomach } \\
(151)\end{array}$ & $\begin{array}{l}\text { Pancreas } \\
\text { (157) }\end{array}$ & $\begin{array}{c}\text { All other } \\
\text { gastro- } \\
\text { intestinal } \\
\text { tract }\end{array}$ & $\begin{array}{l}\text { Lung } \\
\text { (162) }\end{array}$ & $\begin{array}{c}\text { Pleura } \\
163.0\end{array}$ & $\begin{array}{l}\text { Site not } \\
\text { specified } \\
(199)\end{array}$ & $\begin{array}{l}\text { All other } \\
\text { cancers }\end{array}$ & $\begin{array}{c}\text { Total } \\
\text { cancers } \\
(140-209)\end{array}$ \\
\hline $\begin{array}{l}\text { Dockyard } \\
\text { No. } \\
\% \\
\text { Other Plymouth } \\
\text { males } \\
\text { No. } \\
\%\end{array}$ & $\begin{array}{l}28 \\
15 \cdot 6^{*} \\
61 \\
15 \cdot 7\end{array}$ & $\begin{array}{l}3 \\
6 \cdot 5 \\
\\
11 \\
10 \cdot 7\end{array}$ & $\begin{array}{c}10 \\
5 \cdot 2 \\
\\
34 \\
6 \cdot 0\end{array}$ & $\begin{array}{c}13 \\
3 \cdot 6 \\
\\
36 \\
4 \cdot 4\end{array}$ & $\begin{array}{c}0 \\
\text { Nil }\end{array}$ & $\begin{array}{l}2 \\
5 \cdot 0\end{array}$ & $\begin{array}{l}16 \\
2 \cdot 8 \\
\\
52 \\
3 \cdot 1\end{array}$ & $\begin{array}{c}72 \\
5 \cdot 2 \\
201 \\
5 \cdot 6\end{array}$ \\
\hline
\end{tabular}

*Out of 179 registrations at this site, 28 were from death certificates $(15.6 \%)$ 


\section{TABLE 5}

Proportional Registration Ratios for Stomach, Gastrointestinal and Thoracic Cancers for Plymouth Dockyard Workers and Plymouth Males 1960-69, Based on Cancer Registrations in the SOUTH Western Region AND IN ENGLAND AND WALES FOR 1962-68

\begin{tabular}{l|c|c|c|c|c|c}
\hline \multicolumn{1}{c|}{ Population } & \multicolumn{2}{c|}{$\begin{array}{c}\text { Stomach cancer } \\
\text { (ISC No. 151) }\end{array}$} & $\begin{array}{c}\text { Gastrointestinal cancer } \\
\text { (ISC No. 150-9) }\end{array}$ & \multicolumn{2}{|c|}{$\begin{array}{c}\text { Thoracic cancer } \\
\text { (ISC No. 162-3) }\end{array}$} \\
\cline { 2 - 6 } & SW Region & $\begin{array}{c}\text { England } \\
\text { and Wales }\end{array}$ & SW Region & $\begin{array}{c}\text { England } \\
\text { cnd Wales }\end{array}$ & SW Region & $\begin{array}{c}\text { England } \\
\text { and Wales }\end{array}$ \\
\hline $\begin{array}{l}\text { Plymouth dockyard workers } \\
\text { Plymouth males other than dockyard workers }\end{array}$ & 120 & 138 & 111 & 109 & 110 & 93 \\
115 & 108 & 106 & 94 & 79 \\
\hline
\end{tabular}

be analysed separately, and the main findings from the present study are that it confirms a significant excess of pleural tumours but does not show evidence of a significant excess of cancers at any other sites for the dockyard workers as a whole.

The variety of occupations of the dockyard men with registrations for pleural tumours shows that many were at risk of developing a mesothelioma, but it is of interest that none of them was an asbestos lagger or sprayer, who are most heavily exposed to asbestos. The range of occupations of the dockyard workers is also similar to that of the shipyard workers with mesothelial tumours reported by McEwen et al. (1970) in Scotland, Whitwell and Rawcliffe (1971) in the Liverpool area, and Stumphius (1971) in Holland.

The mean number of years of exposure to asbestos and the mean interval between first exposure to asbestos and registration for a pleural tumour could be calculated from data for only 18 and 19 respectively of the 26 men, but the values obtained agree fairly well with those found by Newhouse and Thompson (1965), Whitwell and Rawcliffe (1971), and Elmes, McCaughey, and Wade (1965). The long mean interval between first exposure and registration also indicates that cases of pleural mesothelioma may be expected to occur among these dockyard workers for many years to come although strict precautions are now taken when working with all forms of asbestos which remain in naval ships, and only asbestos-free materials are now used for all new insulation.

The fact that no cases of peritoneal mesothelioma were recorded is likely to be due to lack of awareness of this tumour in the early 1960 s and also because a necropsy examination is required to confirm the diagnosis. One case of peritoneal mesothelioma in a dockyard worker was suspected as a result of a peritoneal biopsy in 1971, but the diagnosis was not confirmed because no necropsy examination was made. A second case was diagnosed clinically in 1974 but this diagnosis has also yet to be fully confirmed.
It is likely that other cases occurred previously which were diagnosed as cancers arising from other sites within the gastrointestinal tract. If so, this might help to account for some of the excess of registrations for cancers of the stomach and pancreas.

Although no significant excesses were found for cancers at sites other than the pleura for dockyard workers as a whole, one of the drawbacks of this study is that it was not possible to categorize the dockyard group according to their asbestos exposure, and it is likely that the risk of developing cancer is greater in those who have been more heavily exposed. As part of an epidemiological study of the health of the employees in all the Royal Naval bases in this country, a mortality study of past and present Devonport dockyard workers is being carried out in which it will be possible to relate causes of death to history of asbestos exposure obtained from employment records and occupational histories. The results of that study should provide more precise information about the relationship between asbestos exposure and cancer.

I am grateful for the permission of the Medical Director General (Naval) to submit this article for publication. I also wish to thank Mr C. E. Rossiter and Surgeon Commander P. G. Harries for their advice, The Director of the South Western Regional Cancer Registry for his permission to study the records at the Plymouth Registry, Mrs E. M. Longstaffe and her staff at the Plymouth Registry for their assistance, and Mrs M. Stevens and Mr G. LeCount who recorded much of the data.

\section{References}

Berry, G., Newhouse, M. L., and Turok, M. (1972). Combined effect of asbestos exposure and smoking on mortality from lung cancer in factory workers. Lancet, 2, 476-479.

Doll, R. (1955). Mortality from lung cancer in asbestos workers. British Journal of Industrial Medicine, 12, 81-86.

Elmes, P. C., McCaughey, W. T. E., and Wade, O. L. 
(1965). Diffuse mesothelioma of the pleura and asbestos. British Medical Journal, 1, 350-353.

and Simpson, M. J. C. (1971). Insulation workers in Belfast. 3. Mortality 1940-66. British Journal of Industrial Medicine, 28, 226-236.

Gerber, M. A. (1970). Asbestosis and neoplastic disorders of the hematopoietic system. American Journal of Clinical Pathology, 53, 204-208.

Harries, P. G. (1968). Asbestos hazards in Naval Dockyards. Annals of Occupational Hygiene, 11, 135-145.

(1971a). The effects and control of diseases associated with exposure to asbestos in Devonport dockyard. Royal Naval Clinical Research Working Party Report, No. 1, pp. 59-102. Institute of Naval Medicine, Alverstoke, Gosport, Hants.

(1971b). The effects and control of diseases associated with exposure to asbestos in Devonport dockyard. Royal Naval Clinical Research Working Party Report, No. 1, pp. 229-253. Institute of Naval Medicine, Alverstoke, Gosport, Hants.

Keal, E. E. (1960). Asbestosis and abdominal neoplasms. Lancet, 2, 1211-1216.

Knox, J. F., Holmes, S., Doll, R., and Hill, I. D. (1968). Mortality from lung cancer and other causes among workers in an asbestos textile factory. British Journal of Industrial Medicine, 25, 293-303.

McDonald, A. D., Harper, A., El Attar, O. A., and McDonald, J. C. (1970). Epidemiology of primary malignant mesothelial tumors in Canada. Cancer, 26, 914-919.

McEwen, J., Finlayson, A., Mair, A., and Gibson, A. A. M. (1970). Mesothelioma in Scotland. British Medical Journal, 4, 575-578.

Newhouse, M. L. (1973). Asbestosis in the workplace and the community. Annals of Occupational Hygiene, 16, 97-107.

and Thompson, H. (1965). Mesothelioma of the pleura and peritoneum following exposure to asbestos in the London area. British Journal of
Industrial Medicine, 22, 261-269.

Registrar General (1968a). Statistical Review of England and Wales 1962-64. Supplement on Cancer, p. 3. HMSO, London.

(1968b). Statistical Review of England and Wales 1962-64. Supplement on Cancer, p. 2. HMSO, London.

Selikoff, I. J., Churg, J., and Hammond, E. C. (1964). Asbestos exposure and neoplasia. Journal of the American Medical Association, 188, 22-26.

- Hammond, E. C., and Churg, J. (1968). Asbestos exposure, smoking, and neoplasia. Journal of the American Medical Association, 204, 106-112.

$\longrightarrow$, $\longrightarrow$, and (1970). Mortality experiences of asbestos insulation workers 1943-68. In Pneumoconiosis: Proceedings of the International Conference, Johannesburg, 1969, edited by H. A. Shapiro, pp. 180-186. Oxford University Press, London and Capetown.

Sheers, G. and Templeton, A. R. (1968). Effects of asbestos in dockyard workers. British Medical Journal, 3, 574-579.

Stell, P. M. and McGill, T. (1973). Asbestos and laryngeal carcinoma. Lancet, 2, 416-417.

Stumphius, J. (1971). Epidemiology of mesothelioma on Walcheren Island. British Journal of Industrial Medicine, 28, 59-66.

Wagner, J. C., Gilson, J. C., Berry, C., and Timbrell, V. (1971). Epidemiology of asbestos cancers. British Medical Bulletin, 27, No. 1, 71-76.

Whitwell, F. and Rawcliffe, R. M. (1971). Diffuse malignant pleural mesothelioma and asbestos exposure. Thorax, 26, 6-22.

World Health Organization (1967). International Statistical Classification of Diseases. WHO, Geneva.

Received for publication 13 November 1975

Accepted for publication 26 February 1976 